\title{
PETA KEKUATAN PARTAI ISLAM DALAM EMPAT ERA PEMERINTAHAN DI INDONESIA
}

\author{
Ruslan Ismail \\ Dosen Tetap Universitas Ekasakti Padang \\ Email : ruslan.mage@gmail.com
}

\begin{abstract}
Peta Kekuatan Partai Islam dalam Empat Era Pemerintahan di Indonesia. Penulisan ini menggunakan metode penelitian kepustakaan. Permasalahan dalam tulisan ini adalah bagaimana kekuatan Partai Politik berbasis Islam di Indonesia dalam empat era pemerintahan, yaitu era Demokrasi Parlementer (1950-1959), Demokrasi Terpimpin (19591965), Orde Baru (1965-1998), dan Reformasi (1999-Sekarang)? Temuannya adalah partai politik berbasis Islam tidak bisa dipisahkan dari tiga dimensi waktu bangsa Indonesia, masa lalu, sekarang dan yang akan datang. Sejak pemilu pertama tahun 1955 sampai pemilu 2014 selalu menjadi bagian penting dari proses politik Indonesia, walaupun belum pernah menjadi pemenang pemilu. Jadi selama ada organisasi kemasyarakatan yang berbasis Islam, selama itu partai Islam akan selalu eksis dan berkibar dalam perpolitikan Indonesia.
\end{abstract}

Kata kunci : partai islam, parlementer, demokrasi terpimpin, orde baru, reformasi

\section{ABSTRACT}

Map of the Strength of Islamic Parties in the Four Governments Era in Indonesia. This writing uses library research methods. The problem in this paper is how the strength of Islamic-based Political Parties in Indonesia in four eras of government, namely the Parliamentary Democracy era (1950-1959), Guided Democracy (1959-1965), New Order (1965-1998), and Reformation (1999-Present)? His findings are that Islam-based political parties cannot be separated from the three time dimensions of the Indonesian people, past, present and future. Since the first elections in 1955 until the 2014 election, it has always been an important part of Indonesia's political process, although it has never been the winner of the election. So long as there is a community organization based on Islam, during this time the Islamic party will always exist and fly in Indonesian politics.

Key words: Islamic party, parliamentary, guided democracy, new order, reform

\section{A. Pendahuluan}

Menulis tentang sejarah partai politik di Indonesia, itu berarti menulis tentang kekuatan partai politik berbasis agama khususnya partai politik yang berideologi Islam. Tidak sulit menemukan data dan fakta sejarah bangsa Indonesia yang bisa menjelaskan bagaimana eksistensi partai politik Islam di negeri ini dari masa ke masa. Bahkan beberapa tahun sebelum kemerdekaan benih-benih partai politik berideologi Islam sudah muncul kepermukaan mengambil peran dalam sejarah pergerakan bangsa. Sebutlah misalnya organisasi Serekat Islam yang 
didirikan tahun 1912 yang kemudian menjadi cikal bakal lahirnya partai politik berbasis Islam.

Dalam catatan sejarah pergerakan bangsa dijelaskan bahwa partai politik pertama-tama lahir dalam zaman kolonial sebagai manifestasi bangkitnya kesadaran nasional. Dalam suasana itu semua organisasi, apakah dia bertujuan sosial (seperti Budi Utomo dan Muhammadiyah) ataukah terang-tarangan menganut asas politik/agama (seperti Sarekat Islam dan Partai Katolik) atau asas politik sekuler (seperti PNI dan PKI), sudah memainkan peran penting dalam berkembangnya pergerakan nasional.

Pergerakan kekuatan partai politik berbasis Islam yang sudah menggeliat di era kolonial terus berlanjut ke zaman pendudukan Jepang (1942-1945). Bahkan pada era ini semua partai politik lama di era kolonial dibubarkan bersamaan dengan pelarangan semua kegiatan-kegiatan politik. Hanya golongan Islam diperkenankan membentuk suatu organisasi sosial yang dinamakan Masyumi, di samping beberapa organisasi baru yang diprakarsai oleh penguasa Jepang.

Partai Islam dalam sejarahnya harus berhadapan dengan kebijakankebijakan pemerintah yang ada. Contohnya pada pemerintahan Orde Baru yang menyederhanakan partai hanya menjadi tiga golongan saja. Perkembangan kemudian menujukkan munculnya reformasi yang membuka kebebasan berpartai. Era reformasi ditandai dengan munculnya ratusan partai politik, tidak terkecuali banyaknya partai yang mengatasnamakan agama, terutama Islam.

Perubahan-perubahan dalam dinamika perpolitikan Indonesia khususnya yang terjadi pada partai politik Islam dari masa ke masa, semakin menujukkan beragamnya pemahaman Islam dan politik partai. Munculnya partai-partai Islam dalam era reformasi sebagai kendaraan politik menuju kekuasaan adalah sebuah dinamika yang menarik mengingat pada era ini warga Indonesia semakin cerdas dan pragmatis dalam menentukan masa depan mereka.

Pesan yang ingin disampaikan dalam tulisan ini adalah bahwa partai politik berbasis Islam tidak bisa dipisahkan dalam sejarah pergerakan di Indonesia, dan selamanya akan selalu diwarnai dengan keterlibatan partai politik berbasis Islam dalam mendesain masa depan bangsa Indonesia. Paling tidak minimal ada dua alasan pembenar eksistensi partai politik berbasis islam di Indonesia yang tidak akan tergerus oleh jaman. Pertama, Indonesia adalah negara yang berpenduduk mayoritas Islam, sehingga munculnya partai Islam sebagai sarana perjuangan tidak terelakkan. Kedua, era demokrasi adalah era semakin berkecambahnya organisasi-organisasi masyarakat, tidak terkecuali organisasi yang berbasis Islam sebagai akar yang kuat tumbuh kembangnya partai politik berbasis Islam. Sehingga selama masih ada organisasi-organisasi kemasyarakatan yang berbasis Islam selama itu partai politik Islam akan selalu berkibar di Indonesia.

\section{B. Pokok Masalah}

Pokok masalah merupakan kalimat tanya dalam suatu laporan penelitian yang fungsinya untuk menunjukkan masalah yang diteliti oleh peneliti dan untuk memberikan batasan-batasan dalam penelitian sehingga penelitian itu tetap fokus pada hal yang benar-benar ingin diteliti tidak melebar ke hal-hal lain. Berdasarkan pengertian tersebut, maka pokok masalah dalam penulisan ini adalah : Bagaimana 
kekuatan Partai Politik berbasis Islam di Indonesia dalam empat era pemerintahan, yaitu era Demokrasi Parlementer (1950-1959), Demokrasi Terpimpin (1959-1965), Orde Baru (1965-1998), dan Reformasi (1999-Sekarang)?

\section{Kerangka Teori}

\section{Partai Politik}

Partai politik adalah sekelompok manusia yang terorganisir secara stabil dengan tujuan untuk merebut atau mempertahankan penguasaan terhadap pemerintahan bagi pimpinan partainya dan beradasarkan penguasaan ini memberikan kepada anggota partainya kemanfaatan yang bersifat idiil maupun materiil. Ia adalah organisasi artikulatif yang terdiri dari pelaku-pelaku politik yang aktif dalam masyarakat, yaitu mereka yang memusatkan perhatiannya pada pengendalian kekuasaan pemerintahan dan yang bersaing untuk memperoleh dukungan rakyat dengan kelompok lain yang mempunyai pandangan yang berbedabeda. Dengan demikian partai politik merupakan perantara yang menghubungkan kekuatan-kekuatandan idilogi-idiologi social dengan lembaga-lembaga pemerintahan yang resmi dan yang mengaitkannya dengan aksi politik didalam masyarakat politik yang lebih luas.

Partai politik sengaja didirikan untuk memperoleh kekuasaan serta memerintah atau mempengaruhi kebijakan pemerintahan. Partai Politik adalah alat yang sah yang ditimbulkan dalam masyarakat modern untuk mengelompokkan berbagai kelompok dan kepentingan dalam masyarakat untuk diartikulasikan dalam kebijakan-kebijakan Negara. Partai politik merupakan alat bagi sekelompok orang yang tergabung secara terorganisir yang memiliki landasan idiologis dan cita-cita yang sama tentang sebuah masyarakat dan negara yang dicita-citakan. Dengan demikian partai politik adalah sarana formal bagi berbagai kelompok masarakat untuk menyalurkan aspirasi dan pandangan politiknya tentang kehidupan masyarakat dan negara yang dicita-citakan.

\section{Islam dan Politik}

Sudah lumprah dan menjadi perdebatan antara Islam dan politik. Ada yang menjelaskan bahwa politik adalah bagian dari Islam tetapi juga ada yang beranggapan bahwa politik lepas dari Islam. Walaupun demikian, sejarah mencatat bahwa perkembangan agama Islam tidak lepas dari dinamika politik seperti contoh kecil adalah Piagam Madinah.

Dalam konteks negara Indonesia, yang notabenenya warga negaranya mayoritas Islam ini, dinamika politik yang ada, khususnya politik Islam memiliki pasang surut dalam percaturan perpolitikan. Indonesia adalah sebuah negara modern yang dimana di dalamnya dalam proses pemerintahannya menggunakan sistem partai dalam menentukan pemerintahannya seperti negara-negara modern lainnya sehingga politik Islam masuk dalam sistem partai.

Dalam proses sejarahnya, partai politik Islam menui dinamika perpolitikan. Hal ini tidak terlepas pluralnya penduduk Indonesia yang bukan hanya Islam saja di dalamnya. Dinamika tersebut dapat terlihat pada track record keikutsertaan partai politik Islam dalam sejarah panjang pemilihan umum di Indonesia. 
Perkembangan sistem partai dalam model pemerintahan modern memunculkan berbagai paradigma pemikiran, tentunya hal ini dikaitkan dengan Islam atau agama vis a vis negara. Secara garis besar hal tersebut dibedakan menjadi tiga paradigma pemikiran. Pertama, paradigma integralistik (unified paradigm). Dalam pandangan paradigma ini agama dan negara menyatu (integrated). Wilayah agama meliputi politik atau negara. Negara merupakan lembaga politik dan keagamaan sekaligus. Karena menurut paradigma ini, kepala negara adalah pemegang kekuasaan agama dan politik. Pemerintahannya diselenggarakan atas dasar "kedaulatan ilahi" (divine sovereignity), karena pendukung paradigma ini meyakini bahwa kedaulatan berasal dalam tangan Tuhan.

Kedua, paradigma simbiotik (simbiotic paradigm), dalam pemahaman paradigma ini, agama dan negara berhubungan secara simbiotik, yaitu suatu hubungan yang bersifat timbal balik dan saling memerlukan. Dalam hal ini, agama memerlukan negara, karena dengan negara, agama dapat berkembang. Sebaliknya negara memerlukan agama, karena dengan agama, negara dapat berkembang dalam etika dan moral spiritual.

Ketiga, paradigma sekuleristik, yaitu paradigma yang menolak kedua pemikiran di atas. Sebagai gantinya, paradigma sekuleristik mengajukan pemisahan antara agama atas negara, begitupun sebaliknya, negara atas agama. Dalam konteks Islam, paradigma ini menolak pendasaran agama Islam atau paling tidak, menolak determinasi Islam pada bentuk tertentu dari negara.

Menurut Azyumardi Azra, Politik Islam kontemporer dapat dilihat dari beberapa kriteria. Pertama, pencantuman Islam sebagai asas partai. Kedua, penggunaan simbol-simbol yang identik atau secara dekat dasosiasikan dengan Islam seperti "bulan bintang", "kabah", "kalimat atau tulisan Arab", dan sebagainya. Ketiga, memiliki basis sosial utama dari kalangan Islam tertentu. Partai Islam juga ditandai oleh adanya personalia kepemiminan partai yang didominasi oleh orangorang yang berlatar belakang Islam yang kuat (santri) serta pengambilan keputusan yang cenderung memihak kepada kepentingan unsur Islam.

Dalam memahami partai politik Islam era reformasi, penelitian ini juga menggunakan kerangka teori politik. Menurut Ramlan Surbakti dalam bukunya "Memahami Ilmu Politik", setidaknya ada tiga teori tentang munculnya Partai Politik antara lain sebagai berikut: 1). Teori Kelembagaan, teori ini mengatakan bahwa partai politik dibentuk oleh kalangan legislatif dan eksekutif, karena ada kebutuhan para anggota parlemen untuk mengadakan kontak dengan masyarakat dan membina dukungan dari masyarakat; 2). Teori Situasi Historis, teori ini mengatakan bahwa partai politik terjadi adanya situasi krisis historis terjadi manakala sistem politik mengalami masa transisi karena perubahan masyarakat dari bentuk trasisional yang berstruktur sederhana menjadi masyarakat modern yang berstruktur kompleks; dan 3). Teori Pembangunan, teori ini mengatakan bahwa partai politik terjadi adanya modernisasi sosial ekonomi, seperti pembangunan teknologi komunikasi berupa media masa dan transportasi, perluasan dan peningkatan pendidikan, industrialisasi, urbanisasi, perluasan kekuasaan negara seperti birokratisasi, pembentukan berbagai kelompok kepentingan dan organisasi profesi, dan peningkatan kemampuan individu yang mempengaruhi lingkungan, melahirkan 
suatu kebutuhan akansuatu organisasi politik maupun memadukan dan memperjuangkan berbagaiaspirasi tersebut.

Surbakti juga menambahkan bahwa di dalam partai politik terdapat juga tipologi-tipologi. Menurut dia, setiap partai politik memiliki asas dan orientasi yang berbeda antara satu dengan lainnya. Semakin banyak kepentingan politik yang diusung oleh partai politik dalam suatu negara, maka ini mencerminkan bahwa kepentingan masyarakat yang ada di negara tersebut beragam. Untuk melihat banyaknya kepentingan dalam suatu negara, maka dapat dilihat dari asas dan orientasi yang di anut dari masing-masing partai politik dalam negara tersebut.

Tipologi partai politik atau juga dikenal dengan istilah partai Cahch-all pertama kali di kemukakan oleh Otto Kirchheimer untuk memberikan tipologi pada kecenderungan perubahan karakteristik. Catch-all dapat diartikan sebagai "menampung kelompok-kelompok sosial sebanyak mungkin untuk dijadikan anggotanya". Tujuan utama partai ini adalah memenangkan pemilihan dengan cara menawarkan program-program dan keuntungan bagi anggotanya sebagai pengganti ideologi yang kaku.

Sebagai bentuk adaptasi dengan lingkungan, partai politik islam merubah dirinya menjadi partai Catch-all dan mengesampingkan ideologi "keislamannya". Hal inilah yang kemudian membuat partai politik islam harus bersaing dengan partai-partai non-agama yang juga merupakan partai Catch-all. Ramlan Surbakti dalam bukunya "Memahami Ilmu Politik" mengklasifikasi asas dan orientasi partai politik menjadi tiga tipe yaitu: 1). Partai politik pragmatis, yaitu suatu partai yang mempunyai program dan kegiatan yang tidak terikat kakupada suatu doktrin dan ideologi tertentu; 2). Partai politik doktriner, yaitu suatu partai politik yang memiliki sejumlah program dan kegiatan konkretsebagai penjabaran ideologi; 3). Partai politik kepentingan, yaitu suatu partai politik yang dibentuk dan dikelola atas dasar kepentingan tertentu, seperti petani, buruh, etnis, agama, atau lingkungan hidup secara langsung ingin berpartisipasi dalam pemerintahan.

\section{Hasil Pembahasan}

\section{Partai Politik Berbasis Islam Era Parlementer (1950-1959)}

Sebagai sebuah negara dengan mayoritas penduduknya beragama Islam maka tidak heran jika banyak pula partai politik yang berasaskan Islam. Pada masa awal kemerdekaan banyak bermunculan partai Islam. Di antaranya adalah Partai Sarekat Islam Indonesia (PSII), Partai Islam Masyumi, Partai Nahdlatul Ulama, Perti, dan lainnya. Berdiri dan berkembangnya organisasi-organisasi Islam telah di mulai sejak masa sebelum kemerdekaan, namun kemudian mengalami kemunduran pada dekade 1930an. Kemudian ketika masa pendudukan Jepang, mereka memberikan dorongan kepada kelompok-kelompok Islam untuk membentuk organisasi tersebut. Setelah Indonesia merdeka pola kepartaian seperti dengan masa penjajahan. Orang nasionalis bergabung dalam Partai Nasional Indonesia (PNI) serta organisasi Islam bersatu dalam Partai Islam Masyumi.

Setelah penyerahan kedaulatan 27 Desember 1949, sejarah politik Indonesia memasuki babak baru dengan diterapkannya sistem demokrasi parlementer dan konstitusi UUD RIS 1949 yang kemudian diganti dengan UUDS 1950. Pada tahun 1950-1957 ditandai dengan jatuh bangunnya partai-partai politik yang berumur rata- 
rata kurang dari setahun. Setelah NU keluar dari Masyumi, parpol Islam diwakili oleh Masyumi, NU, PSII, dan Perti. Ciri lainnya tidak satu pun parpol yang mayoritas. Pada masa revolusi, PNI dan Masyumi sering mengadakan kerjasama, namun pada masa ini hubungannya tidak serasi lagi, bahkan dalam saat-saat tertentu sama sekali terputus. Untuk mengetahui bagaimana peta kekuatan partai Islam dari pemilu ke pemilu, berikut deskripsinya.

\section{a. Pemilu I Tahun 1955}

Pemilu pertama dalam sejarah bangsa Indonesia dilaksanakan tahun 1955. Waktu itu Republik Indonesia berusia 10 tahun. Kalau dikatakan pemilu merupakan syarat minimal bagi adanya demokrasi, apakah berarti selama 10 tahun itu Indonesia benar-benar tidak demokratis? Tidak mudah juga menjawab pertanyaan tersebut. Yang jelas, sebetulnya sekitar tiga bulan setelah kemerdekaan diproklamasikan oleh Soekarno dan Hatta pada 17 Agustus 1945, pemerintah waktu itu sudah menyatakan keinginannya untuk bisa menyelenggarakan pemilu pada awal tahun 1946.

Hal itu dicantumkan dalam Maklumat No. X, atau Maklumat Wakil Presiden Mohammad Hatta tanggal 3 Nopember 1945, yang berisi anjuran tentang pembentukan partai-partai politik. Maklumat tersebut menyebutkan, pemilu untuk memilih anggota DPR dan MPR akan diselenggarakan bulan Januari 1946. Kalau kemudian ternyata pemilu pertama tersebut baru terselenggara hampir sepuluh tahun tentu bukan tanpa sebab.

Keterlambatan dan penyimpangan tersebut bukan tanpa sebab pula. Ada kendala yang bersumber dari dalam negeri dan ada pula yang berasal dari faktor luar negeri. Sumber penyebab dari dalam antara lain ketidaksiapan pemerintah menyelenggarakan pemilu, baik karena belum tersedianya perangkat perundangundangan untuk mengatur penyelenggaraan pemilu maupun akibat rendahnya stabilitas keamanan negara. Dan yang tidak kalah pentingnya, penyebab dari dalam itu adalah sikap pemerintah yang enggan menyelenggarakan perkisaran (sirkulasi) kekuasaan secara teratur dan kompetitif. Penyebab dari luar antara lain serbuan kekuatan asing yang mengharuskan negara ini terlibat peperangan.

Patut dicatat dan dibanggakan bahwa pemilu yang pertama kali tersebut berhasil diselenggarakan dengan aman, lancar, jujur dan adil serta sangat demokratis. Pemilu 1955 bahkan mendapat pujian dari berbagai pihak, termasuk dari negara-negara asing. Pemilu ini diikuti oleh lebih 30-an partai politik dan lebih dari seratus daftar kumpulan dan calon perorangan.

Menarik dari Pemilu 1955 adalah tingginya kesadaran berkompetisi secara sehat. Misalnya, meski yang menjadi calon anggota DPR adalah perdana menteri dan menteri yang sedang memerintah, mereka tidak menggunakan fasilitas negara dan otoritasnya kepada pejabat bawahan untuk menggiring pemilih yang menguntungkan partainya. Karena itu sosok pejabat negara tidak dianggap sebagai pesaing yang menakutkan dan akan memenangkan pemilu dengan segala cara. Karena pemilu kali ini dilakukan untuk dua keperluan, yaitu memilih anggota DPR dan memilih anggota Dewan Konstituante, maka hasilnya pun perlu dipaparkan semuanya.

Pada pemilu pertama ini cukup banyak partai politik ikut serta di dalam pemilu. Data menujukan ada 28 partai politik peserta pemilu 1955. Namun, hanya 
empat partai yang memperoleh suara terbesar dengan memiliki garis ideologi yang cukup berseberangan antara satu sama lain, yaitu PNI (Partai Nasional Indonesia) meraih 22,32\% suara dan mengantungi 57 kursi di parlemen. Masyumi (Majelis Syuro Muslimin Indonesia) meraih 20,92\% suara dan mengantungi 57\% suara di parlemen. NU (Nahdlatul Ulama) meraih 18,41\% suara dan $45 \%$ suara di parlemen. PKI (Partai Komunis Indonesia) meraih 16,36\% suara dan meraih 39 kursi di parlemen.

Dari hasil perolehan suara hasil Pemilu pertama 1955 ini menunjukkan bahwa partai politik berbasis Islam banyak mendominasi. Bahkan Masyumi sama jumlah perolehan kursinya dengan PNI sebagai pemenang suara terbanyak yaitu 57 kursi. Disusul NU (Nahdlatul Ulama) yang menempati urutan ketiga dengan 45 kursi, kemudian PKI di rutan keempat dengan 39 kursi. Di urutan kelima kembali partai politik berbasis Islam yaitu Partai Syarikat Islam Indonesia berhasil menyingkirkan partai-partai politik lainnya dengan perolehan kursi 8. Baru kemudian urutan berikutnya Patai Keristen Indonesia dan Partai Katolik. Lebih jelanya berikut tabel hasil perolehan suara pada pemilu pertama tahun 1955 yang berlangsung damai dengan tingkat partisipasi rakyat yang tinggi.

Tabel 1

Hasil Perolehan Suara Pemilu Pertama 1955

\begin{tabular}{|c|l|r|r|c|}
\hline NO & \multicolumn{1}{|c|}{ NAMA PARTAI } & \multicolumn{1}{c|}{ SUARA } & \multicolumn{1}{c|}{ KURSI } & KUR \\
\hline 1 & Partai Nasional Indonesia (PNI) & 8.434 .653 & 22,32 & 57 \\
\hline 2 & Masyumi & 7.903 .886 & 20,92 & 57 \\
\hline 3 & Nahdatul Ulama (NU) & 6.955 .141 & 18,41 & 45 \\
\hline 4 & Partai Komunis Indonesia (PKI) & 6.179 .914 & 16,36 & 39 \\
\hline 5 & Partai Syarikat Islam Indonesia & 1.091 .160 & 2,89 & 8 \\
\hline 6 & Patai Keristen Indonesia & 1.003 .326 & 2,66 & 8 \\
\hline 7 & Partai Katolik & 770.740 & 2,04 & 6 \\
\hline 8 & Partai Sosialis Indonesia (PSI) & 753.191 & 1,99 & 5 \\
\hline 9 & Ikatan Pendukung Kemerdekaan & 541.306 & 1,43 & 4 \\
& Indonesia (IPKI) & & & \\
\hline 10 & Pergerakan Tarbiyah Islamiyah & 483.014 & 1,28 & 4 \\
\hline 11 & Partai Rakyat Nasional (PNI) & 242.125 & 0,64 & 2 \\
\hline 12 & Partai Buruh & 224.167 & 0,59 & 2 \\
\hline 13 & Gerakan Pembela Pancasila & 219.985 & 0,58 & 2 \\
\hline 14 & Partai Rakyat Indonesia & 206.161 & 0,55 & 2 \\
\hline 15 & Persatuan Pegawai Polisi RI & 200.419 & 0,53 & 2 \\
\hline 16 & Murba & 199.588 & 0,53 & 2 \\
\hline 17 & Baperki & 178.887 & 0,47 & 1 \\
\hline 18 & Persatuan Indonesia Raya & 178.481 & 0,47 & 1 \\
\hline 19 & Grinda & 154.792 & 0,41 & 1 \\
\hline 20 & Persatuan Rakyat Marhaen Indonesia & 149,287 & 0,40 & 1 \\
\hline 21 & Persatuan Daya (PD) & 146.054 & 0,39 & 1 \\
\hline 22 & PIR Hazairin & 114.644 & 0,30 & 1 \\
\hline 23 & Partai Politik Tarikat Islam (PPTI) & & 0,22 & 1 \\
\hline
\end{tabular}




\begin{tabular}{|c|l|r|c|c|}
\hline 24 & AKUI & 81.454 & 0,21 & 1 \\
\hline 25 & Persatuan Rakyat Desa (PRD) & 77.919 & 0,21 & 1 \\
\hline 26 & Partai Republik Indonesia Merdeka & 72.523 & 0,19 & 1 \\
\hline 27 & Angkatn Comunis Muda (Acoma) & 64.514 & 0,17 & 1 \\
\hline 28 & R. Soedjono Prawinsoedarso & 53.306 & 0,14 & 1 \\
\hline 29 & Lain-lain & 1.022 .433 & 2,71 & --- \\
\hline & JUMLAH & $\mathbf{3 7 . 7 8 5 . 2 9 9}$ & $\mathbf{1 0 0 , 0 0}$ & $\mathbf{2 5 7}$ \\
\hline
\end{tabular}

Sumber : http//www.id.wikipedia.org/pemilu_1955

\section{Partai Politik Berbasis Islam Era Demokrasi Terpimpin (1950-1959)}

Periode ini ditandai oleh beberapa ciri, yaitu pertama, peran domminan dari Presiden, kedua, pembatasan atas peran DPR serta partai-partai politik, kecuali PKI yang melahan mendapat kesempatan untuk berkembang, dan ketiga, peningkatan peran ABRI sebagai kekuatan sosial politik. Selain dari itu dimulailah beberapa usaha untuk menyederhanakan sistem partai dengan mengurangi jumlah partai melalui Penpres No. 7/1959. Maklumat Pemerintah No. 3 November 1945 yang menganjurkan pembentukan partai-partai politk dicabut dan ditetapkan syarat-syarat yangharus dipenuhi oleh partai unutk diakui olegh pemerintah. Partai yang kemudian dinyatakan memenuhi syarat adalah PKI, PNI, NU, Partai Katolik, Partindo- Parkindo, Partai Murba, PSII Arudji, IPKI, Partai Islam Perti. Sedangkan beberapa partai lain dinyatakan tidak memenuhi syarat. Dengan dibubarkannya Masjumi dan PSI pada tahun 1960 tinggal sepuluh partai politik saja.

Pada era Demokasi Terpimpin ini, partai politik berbasis Islam mengalami distrosi yang luar biasa. Sepertinya ada gerakan pembusukan yang menyerang partai politik berbasis Islam. Terlebih pada pemilu pertama 1955 partai politik berbasis Islam memperlihatkan dominasinya dari segi perolehan suara dan kursi. Bisa jadi hasil pemilu 1955 ini menjadi warning kelompok lain yang sangat frustasi melihat fenomena Masjumi dan NU menempati urutan kedua dan ketiga perolehan kursi, sehingga harus didesain untuk menyingkirkan Masjumi dari arena politik Indonesia. Hasilnya luar biasa, ketika terjadi gejolak di beberapa daerah, Masyumi diidentifikasikan dengan pemberontakan tersebut sehingga pada tahun 1960 dua partai politik berbasis Islam yaitu Masyumi dibubarkan. ${ }^{i}$ Menyusul kemuudian PSI.

Sangat disayangkan, kisah sukses Pemilu 1955 akhirnya tidak bisa dilanjutkan dan hanya menjadi catatan emas sejarah. Pemilu pertama itu tidak berlanjut dengan pemilu kedua lima tahun berikutnya. Terjadi krisis politik berkepanjangan sampai Presiden Soekarno diberhentikan oleh MPRS melalui Sidang Istimewa bulan Maret 1967 (Ketetapan XXXIV/MPRS/ 1967) setelah meluasnya krisis politik, ekonomi dan sosial pasca kudeta G 30 S/PKI yang gagal semakin luas, rezim yang kemudian dikenal dengan sebutan Demokrasi Terpimpin itu tidak pernah sekalipun menyelenggarakan pemilu. Malah tahun 1963 MPRS yang anggotanya diangkat menetapkan Soekarno, orang yang mengangkatnya, sebagai presiden seumur hidup. Ini adalah satu bentuk kekuasaan otoriter yang mengabaikan kemauan rakyat tersalurkan lewat pemilihan berkala. 


\section{Partai Politik Berbasis Islam Era Orde Baru (1965-1998)}

Ketika Jenderal Soeharto diangkat oleh MPRS menjadi pejabat Presiden menggantikan Bung Karno dalam Sidang Istimewa MPRS 1967, ia juga tidak secepatnya menyelenggarakan pemilu untuk mencari legitimasi kekuasaan transisi. Malah Ketetapan MPRS XI Tahun 1966 yang mengamanatkan agar Pemilu bisa diselenggarakan dalam tahun 1968, kemudian diubah lagi pada SI MPR 1967, oleh Jenderal Soeharto diubah lagi dengan menetapkan bahwa Pemilu akan diselenggarakan dalam tahun 1971. Lebih jelasnya berikut deskripsi peta kekuatan partai politik berbasis Islam selama era Orde Baru.

\section{b. Pemilu II Tahun 1971}

Pada Pemilu II dan I setelah era Orde Baru diikuti oleh sepuluh organisasi sosial politik (orsospol), yaitu sembilan partai dan satu golongan berkarya (Golkar). Saat itu sistim kepartaian sudah mengalami penyederhanaan sedemikian rupa. Namun faktanya walaupun partai-partai politik sudah mengalami penyederhanaan, namun faktanya partai politik berbasis Islam kembali memperlihatkan kekuatannya. Walaupun Golkar yang mendapat dukungan penuh dari kekuasaan tetap menjadi pemenang pertama pada pemilu 1971, namun urutan kedua sampai kelima didominasi oleh partai politk berbasis Islam. Lebih jelasnya berikut tabel hasil perolehan suara pada pemilu kedua tahun 1971.

Tabel 2

Hasil Perolehan Suara Pemilu II 1971

\begin{tabular}{|c|l|r|r|c|}
\hline NO & \multicolumn{1}{|c|}{ NAMA PARTAI } & \multicolumn{1}{c|}{ SUARA } & \multicolumn{1}{c|}{ \% } & \multicolumn{1}{c|}{ KURSI } \\
\hline 1 & Golkar & 34.348 .673 & 62,82 & 236 \\
\hline 2 & Nahhdatul Ulama (NU) & 10.213 .650 & 18,68 & 58 \\
\hline 3 & Partai Nasional Indonesia (PNI) & 3.793 .266 & 6,93 & 28 \\
\hline 4 & Parmusi & 2.930 .746 & 5,36 & 24 \\
\hline 5 & Partai Syarikat Islam Indonesia & 1.308 .237 & 2,39 & 10 \\
\hline 6 & Arai Kristen Indoonesia & 733.359 & 1,34 & 7 \\
\hline 7 & Partai Katolik & 603.740 & 1,10 & 3 \\
\hline 8 & Pergerakan Tarbiyah Islamiyah & 381.309 & 0,69 & 2 \\
\hline 9 & Ikatan Pendukung Kemerdekaan & 338.403 & 0,61 & - \\
\hline 10 & Indoesia & & & \\
\hline & Murba & 48.126 & 0,08 & - \\
\hline
\end{tabular}

Sumber : kpu.go.id/index.php/pages/detail/2017/9/PEMILU-1971

Dengan memperhatikan komposisi hasil perolehan suara seperti pada tabel kedua di atas, kita bisa berasumsi bahwa kalau saja Golkar tidak diproteksi oleh penguasa, bisa jadi partai politik berbasis Islam menyapu bersih lima besar perolehan kursi di parlemen. Kondisi ini membuktikan bahwa bangsa Indonesia tidak bisa bangkit, berjalan, apalagi berlari mensejajarkan diri dengan bangsa yang sudah maju, tampa dukungan dari partai politik berbasis Islam, mengingat mayoritas penduduk Indonesia adalah orang Islam. 


\section{c. Pemilu III Tahun 1977}

Melihat realitas sosial politik yang terjadi pasca pemilu kedua 1971 yang memperlihatkkan Golkar bisa terancam dominasinya oleh partai politik berbasis Islam, bisa menjadi peyebab Presiden Soeharto mengemukakan sarannya agar partai mengelompokkan diri untuk mempermudah kampanye pemilihan umum tanpa partai kehilangan identitas masing-masing atau dibubarkan sama sekali. Pengelompokan ini mencakup tiga kelompok, yaitu Golongan Nasional, Golongan Spiritual, dan Golongan Karya.

Akhirnya pengelompokan dalam tiga golongan ini baru terjadi pada tahun 1973. Empat partai Islam, yaitu Nahdatul Ulama, Partai Muslimin Indonesia, Partai Sarekat Islam Indonesia, dan Perti (Persatuan Tarbiyah Islamiyah) bergabung menjadi Partai Persatuan Pembangunan (PPP). Kemudian lima partai, yaitu Partai Nasional Indonesia, Partai Kristen Indonesia, Partai Katolik, Partai Murba, dan Partai Ikatan Pendukung Kemmerdekaan Indonesia (IPKI) bergabung menjadi Partai Demokrasi Indonedsia (PDI). Dengan demikian mulai Pemilu 1977 hanya ada tiga orsospol, yaitu PPP, PDI dan Golkar sebagai peserta pemilu.

Dari sinilah mulainya partai politik berbasis Islam mengalami masa-masa paceklik karena terkoptasi oleh penguasa. Namun walaupun terus mengalami ketidakadilan dalam proses pemilu, namun partai politik Islam dbawah payung PPP tetap berjuang meraih suara, walupun hasil pemilu sidah dapat diprediksi atau dipastikan selalu dimenangkan Golkar yang didukung penuh oleh penguasa. Hasilnya PPP yang rohnya digerakkan oleh partai-partai politik berbasis Islam tetap selalu berada di urutan kedua hasil perolehan suara setiap pemilu. Lebih jelasnya berikut tabel hasil perolehan suara Pemilu selama Orde Baru pada tahun 1977, 1982, 1987, 1992, 1997.

Tabel 3

Hasil Perolehan Suara Pemilu III 1977

\begin{tabular}{|c|l|r|r|c|}
\hline NO & NAMA PARTAI & \multicolumn{1}{c|}{ SUARA } & \multicolumn{1}{c|}{$\%$} & \multicolumn{1}{c|}{ KURSI } \\
\hline 1 & Golkar & 39.750096 & 62,11 & 232 \\
\hline 2 & PPP & 11.743 .491 & 29,29 & 99 \\
\hline 3 & PDI & 5.504757 & 8,60 & 29 \\
\hline & & $\mathbf{6 3 . 9 9 8 . 3 4 4}$ & $\mathbf{1 0 0 , 0 0}$ & $\mathbf{3 6 0}$ \\
\hline
\end{tabular}

Sumber: $\underline{w w}$.rumahpemilu.com

\section{d. Pemilu IV Tahun 1982}

Pada pemilu IV tahun 1982 komposisi perolehan suara tetap sama pada pemilu III tahun 1977, pertama tetap Golkar, kemudian PPP, dan baru PDI. Namun terjadi kenaikan jumlah suara PPP, walaupun prosentase dan perolehan kursi menurun sebagai akibat sistem pembagian kursi yang menggunakan sistem proporsional di daerah pemilihan. Lebih jelasnya berikut tabel hasil perolehan suara pada pemilu IV tahun 1982. 
Tabel 4

Hasil Perolehan Suara Pemilu IV 1982

\begin{tabular}{|c|c|c|c|c|}
\hline NO & NAMA PARTAI & SUARA & $\%$ & KURSI \\
\hline 1 & Golkar & 48.334 .724 & 64,34 & 242 \\
\hline 2 & PPP & 20.871 .880 & 27,78 & 94 \\
\hline 3 & PDI & 5.919 .702 & 7,88 & 24 \\
\hline & JUMLAH & 75.126 .306 & 100,00 & 364 \\
\hline
\end{tabular}

Sumber : kepustakaan-presiden.pnri.go.id

\section{e. Pemilu V Tahun 1987}

Data dan fakta politik yang terjadi pada Pemilu V tahun 1987 tidak berbeda dengan Pemilu IV 1982. Komposisi suara tetap sama dengan selalu menempatkan Golkar sebegai pemenang suara dan kursi terbanyak, kemudian disusul PPP dan PDI. Mobilitas partai Islam mengalami penggembosan suara dihampir semua lini kehidupan masyarakat. Bahkan dalam Pemilu V 1987 ini suara PPP mengalami penurunan jumlah suara dan kursi. Sementara disaat yang bersamaan PDI mengalami kenaikan jumlah suara dan kursi. Sejak tahun 1987 ini mulai terlihat kecenderungan penurunan jumlah suara dan kursi PPP. Lebih jelasnya berikut tabel hasil perolehan suara pada Pemilu V 1987.

Tabel 5

Hasil Perolehan Suara Pemilu V 1987

\begin{tabular}{|c|l|r|r|c|}
\hline NO & NAMA PARTAI & \multicolumn{1}{c|}{ SUARA } & \multicolumn{1}{c|}{ \% } & \multicolumn{1}{c|}{ KURSI } \\
\hline 1 & Golkar & 62.783 .680 & 73,16 & 299 \\
\hline 2 & PPP & 13.701 .428 & 15,97 & 61 \\
\hline 3 & PDI & 9.384 .708 & 10,87 & 40 \\
\hline & & $\mathbf{8 5 . 8 6 9 . 8 1 6}$ & $\mathbf{1 0 0 , 0 0}$ & $\mathbf{4 0 0}$ \\
\hline
\end{tabular}

Sumber : kepustakaan-presiden.pnri.go.id

f. Pemilu VI Tahun 1992

Pada Pemilu VI tahun 1992 komposisi perolehan suara tetap terulang sama dengan tiga pemilu sebelumnya. Dimana Golkar selalu keluar sebagai jawaranya. Namun yang menarik dikritisi adalah kekuatan konsolidasi PPP sebagai partai berbasis Islam cenderung mengalami stagnasi, sehingga hanya mampu meningkatkan satu jumlah kursi menjadi 62 kursi dari Pemilu V 1987 yaitu 61 kursi. Sementara di satu sisi PDI memperlihatkan penambahan kursi yang relatif tinggi yaitu 15 kursi menjadi 56 kursi dari pemilu sebelumnya 40 kursi. Kenaikan suara PDI ini ditengarai bergabungnya Megawati Sukarnoputri, putri mantan presiden Sukarno, selaku pimpinan partai. Sejumlah emosi dan kekecewaan atas pemerintahan Orde Baru mulai diarahkan pada upaya pendukungan masyarakat atas partai ini. Lebih jelasnya berikut tabel hasil perolehan jumlah kursi pada pemilu VI tahun 1992. 
Tabel 6

Hasil Perolehan Suara Pemilu VI 1992

\begin{tabular}{|c|l|c|c|c|}
\hline NO & NAMA PARTAI & SUARA & \% & KURSI \\
\hline 1 & Golkar & 66.599 .331 & 68,10 & 282 \\
\hline 2 & PPP & 16.624 .647 & 17,01 & 62 \\
\hline 3 & PDI & 14.565 .556 & 14,89 & 56 \\
\hline & \multicolumn{2}{|r|}{} \\
\hline
\end{tabular}

Sumber : www.partai.info/pemilu1992

\section{g. Pemilu VII 1997}

Pada Pemilu VII tahun 1997 lagi-lagi Golkar dengan dukungan seluruh kekuasaan kembali memperlihatkan dominiasinya. Namu yang menarik adalah fenomena kebangkitan partai politik berbasis Islam PPP yang berhasil menambah jumlah suara dan kursi yang sangat signifikan meninggalkan jauh perolehan suara dan kursi PDI. Belajar dari dua pengalaman pemilu sebelumnya yang mengalami penurunan suara sehingga hampir terkejar sama PDI, PPP berhasil melakukan konsolidasi partai yang berakibat positif kepada hasil perolehan suara dan kursi di parlemen. Pada Pemilu VII tahun 1997 ini PPP berhasil menambah kursinya sebanyak 27 kursi menjadi 89 kursi dari pemilu sebelumnya 62 kursi. Kenaikan suara dan kursi PPP ini disinyalir karena presiden Soeharto mulai mendekat kepada kelompok Islam, sehingga suara PPP bisa meningkat 5,43\%. Saat yang bersamaan PDI mengalami penurunan drastis jumlah kursi menjadi hanya 11 kursi. Salah satu penyebabnya adalah, intimidasi yang dilakukan pemerintah atas kepemimpinan PDI Megawati Sukarnoputri berikut pendukungnya. Seperti diketahui, saat itu PDI mengalami dualisme kepemimpinan, satu PDI versi Suryadi/Fatimah Ahmad, dan PDI versi Megawati Sukarnoputri. Lebih jelasnya berikut tabel jumah perolehan kursi di parlemen pada Pemilu VII tahun 1997.

Tabel VII

Hasil Perolehan Suara dan Kursi Pemilu VII 1997

\begin{tabular}{|c|c|c|c|c|}
\hline NO & NAMA PARTAI & SUARA & $\%$ & KURSI \\
\hline 1 & Golkar & 84.187 .907 & 74,51 & 325 \\
\hline 2 & PPP & 23.340 .028 & 22,43 & 89 \\
\hline 3 & PDI & 3.463 .225 & 3,06 & 11 \\
\hline & JUMLAH & 112.991 .150 & 100,00 & 425 \\
\hline
\end{tabular}

Sumber : www.partai.info/pemilu1997

\section{Partai Politik Berbasis Islam Era Orde Reformasi (1998-Sekarang)}

Pasca Reformasi Indonesia dilanda redemokratisasi, suatu proses perjalan panjang dari sistem politik yang cenderung otoriter di era Orde Baru menuju sistem politik demokrasi yang mengedepankan kebebasan dihamnir segala lini kehiduan berbangsa dan bernegara, tidak terkecuali di bidang politik. Kebijakan Presiden B.J.Habibie yang membebaskan berdirinya partai politi, disambut dengan lahirnya ratusan partai politik baru di Indonesia yaitu paling tidak 181 partai politik, yang dilanjutkan dengan pelaksanaan pemilu yang dipercepat pada bulan Juni 1999. 
Dalam pemilu pertama masa reformasi itu, tidak seluruh partai politik yang terdaftar bisa ikut pemulu, karena setelah dilakukan verifikasi oleh Komisi Pemilihan Umum pemilu tersebut hanya diikuti oleh 48 partai Politik. Pemilu ini, dianggap sebagai pemilu paling demakratis yang dilasanakan oleh bangsa Indonesia sepanjang sejarahnya setelah Pemilu pertama pada tahun 1955. Dari seluruh partai politik peserta pemilu tersebut paling tidak terdapat 8 partai politik Islam.

\section{a. Pemilu I Pasca Reformasi 1999}

Hasil Pemilu tahun 1999, menunjukkan bahwa ternyata perolehan partai politik Islam sangatlah kecil dibanding dengan perolehan suara partai politik yang tidak berdasarkan Islam seperti PDI dan Partai Golkar. Partai Persatuan Pembangunan (PPP) yang telah berumur hampir $1 / 4$ abad hanya memperoleh 58 kursi DPR dari 462 kursi yang diperebutkan. PKB memperoleh 51 kursi, PAN memperoleh 34 kursi, Partai Bulan Bintang memperoleh 13 kursi, Partai Keadilan memperoleh 7 kursi atau 1,5\%, Partai Nahdatul Ummah memperoleh 5 kursi, serta 3 partai Islam lain yang meperoleh kursi masing-masing 1 kursi, yaitu Partai Kebangkitan Ummat, Partai Syarikat Islam serta Partai Masyumi sehingga berjumlah 3 kursi atau 0,64\%. Lebih jelasnya berikut tabel 10 besar perolehan suara dan kursi pada Pemilu VII tahun 1999 dan pertama pasca Reformasi.

\section{Tabel VIII}

\section{Hasil Perolehan Suara dan Kursi Pemilu VIII 1999}

\section{Peserta : 48 Partai Politik}

\begin{tabular}{|c|l|r|r|c|}
\hline NO & NAMA PARTAI & \multicolumn{1}{c|}{ SUARA } & \multicolumn{1}{c|}{$\%$} & \multicolumn{1}{c|}{ KURSI } \\
\hline 1 & PDI Perjuangan & 33.689 .073 & 33,74 & 153 \\
\hline 2 & Partai Golkar & 23.741 .749 & 22,44 & 120 \\
\hline 3 & PPP & 11.329 .905 & 10,71 & 58 \\
\hline 4 & PKB & 13.336 .982 & 12,61 & 51 \\
\hline 5 & PAN & 7.528 .956 & 7,12 & 34 \\
\hline 6 & PBB & 2.049 .708 & 1,94 & 13 \\
\hline 7 & PK (PKS) & 1.436 .565 & 1,36 & 7 \\
\hline 8 & PNU & 679.179 & 0,64 & 5 \\
\hline 9 & PDKB & 550.846 & 0,52 & 5 \\
\hline 10 & PKP & 1.065 .686 & 1,01 & 4 \\
\hline
\end{tabular}

Sumber : www.partai.info/pemilu1999

\section{b. Pemilu II Pasca Reformasi 2004}

Hasil final verifikasi faktual KPU telah menetapkan 24 partai politik yang berhak menjadi peserta Pemilu 2004. Dari 24 parpol itu, ada tujuh partai Islam, yakni PKB, PPP, PKS, PAN, PBB, PBR, dan PPNUI Ketujuh partai itu sebenarnya tidak jauh berbeda dengan partai-partai peserta Pemilu 1999, hanya berubah nama atau pecahan dari partai sebelumnya.

Jumlah partai Islam yang ikut dalam Pemilu 2004 berkurang secara drastis dibandingkan dengan Pemilu 1999. Menciutnya jumlah partai Islam pada Pemilu 2004 merupakan fenomena baru setelah eforia umat Islam mendirikan partai pada 
Pemilu 1999. Saat itu ada 11 partai Islam yang ikut menjadi peserta pemilu : PPP, PBB, PKU, PK, PNU, Partai SUNI, Masyumi Baru, PPIM, PUI, PSII, dan PSII 1905. Berarti, ada penurun yang cukup signifikan dari partai-partai Islam yang terlibat dalam Pemilu 2004 yang hanya berjumlah tujuh partai Islam.

Mengapa terjadi penciutan jumlah partai-partai Islam pada Pemilu 2004? Salah satu alasannya adalah secara prosedural, keikutsertaan partai-partai peserta pemilu harus lolos verifikasi secara administratif dan verifikasi faktual di semua provinsi. Akibatnya, hampir semua partai baru, termasuk partai-partai Islam, kesulitan memenuhi jumlah minimal verifikasi faktual. Menciutnya jumlah partaipartai Islam pada Pemilu 2004 akibat masalah prosedural sehingga hanya bisa menambah tiga partai yang semuanya reinkarnasi partai Islam pada Pemilu 1999 atau pecahan dari partai yang sudah mapan. PKS dan PPNUI adalah reinkarnasi dari PK dan PNU, PBR adalah pecahan PPP, sedangkan PBB dan PPP adalah partai peserta pemilu yang lolos secara otomatis karena melebihi electoral threshold pada Pemilu 1999.

Menciutnya jumlah partai Islam sebenarnya memberi pelajaran berharga bagi umat Islam untuk kembali memikirkan bangsa, bukan sekadar memperjuangkan aliran dan kelompoknya dalam kancah politik, yang justru membawa permusuhan dan konflik antarumat Islam. Bukankah dulu dengan banyaknya partai Islam justru membawa aroma konflik yang luar biasa di tengah masyarakat? Inilah momentum tepat untuk memperjuangkan aspirasi umat dan memajukan bangsa demi terwujudnya cita-cita keadilan, kemakmuran, dan kesejahteraan.

Kompisisi perolehan suara dan kursi partai Islam tidak jauh berbeda pada pemilu 1999. Pada pemilu 2004 tetap berada diurutan ketiga dan tidak mampu mengalahkan dua besar pertai pemenang pemilu 1999, yaitu PDIP dan Golkar. Hanya pada pemilu 2004 Partai Golkar berhasil mengambil alih podidi pertama dari PDIP. Dari sepuluh besar hasil perolehan jumlah suara dan kursi pada pemilu 2004 tercatat enam partai Islam berhasil masuk didalamnya. PKB menduduki urutan ketiga dengan jumlah suara 11.989.564 dengan 52 kursi, urutan keempat PPP dengan jumlah suara 9.248.764 dengan 58 kursi, dan urutan keenam sampai kesembilan perolehan suara dan kursi dikuasai partai Islam. Sementara satu partai Islam yang hanya mampu meraih suara 895.610 dan tidak mendapatkan kursi adalah Partai Persatuan Nahdatul Ummah (PPNUI). Lebih jelasnya berikut sepuluh besar hasil jumlah perolehan suara dan kursi pada pemilu 2004.

Tabel IX

Hasil Perolehan Suara dan Kursi Pemilu II Pasca Reformasi 2004 Peserta : 24 Partai Politik

\begin{tabular}{|c|l|r|r|c|}
\hline NO & \multicolumn{1}{|c|}{ NAMA PARTAI } & \multicolumn{1}{c|}{ SUARA } & \multicolumn{1}{c|}{$\%$} & \multicolumn{1}{c|}{ KURSI } \\
\hline 1 & Partai Golongan karya & 24.480 .757 & 21,58 & 128 \\
\hline 2 & PDIP & 21.026 .629 & 18,53 & 109 \\
\hline 3 & PKB & 11.989 .564 & 10,57 & 52 \\
\hline 4 & PPP & 9.248 .764 & 8,15 & 58 \\
\hline 5 & Partai Demokrat & 8.455 .225 & 7,45 & 57 \\
\hline 6 & PKS & 8.325 .020 & 7,34 & 45 \\
\hline 7 & PAN & 7.303 .324 & 6,44 & 52 \\
\hline
\end{tabular}




\begin{tabular}{|c|l|r|r|l|}
\hline 8 & PBB & 2.970 .487 & 2,62 & 11 \\
\hline 9 & PBR & 2.764 .998 & 2,44 & 13 \\
\hline 10 & Partai Damai Sejahtera & 2.414 .254 & 2,13 & 12 \\
\hline
\end{tabular}

Sumber : www.partai.info/pemilu2004

\section{c. Pemilu III Pasca Reformasi 2009}

Berdasarkan data KPU, Sabtu, 09 Mei 2009, jumlah peserta pemilu 2009 adalah 44 partai politik. Dari 44 partai politik peserta pemilu, delapan di antaranya merupakan partai politik (parpol) Islam. Dari kedelapan parpol Islam tersebut, empat di antaranya parpol Islam lama, yaitu PPP, PKS, PBB, dan PBR, sedangkan dua lainnya merupakan parpol Islam pendatang baru, yaitu PMB dan PKNU. Partai Matahari Bangsa (PMB) adalah partai yang didirikan oleh kalangan Muhammadiyah yang tidak puas dengan keberadaan PAN yang dianggap tidak memperjuangkan aspirasi dan orang-orang Muhammadiyah. Berbeda dengan PAN yang berasaskan Pancasila, PMB jelas-jelas mencantumkan Islam sebagai asas partai dengan visi terwujudnya misi Islam rahmatan lil'alamin.

Sementara itu Dr. Lili Romli membagi kedelapan partai ini ke dalam dua aliran Islam, yaitu Islam Formalis dan Islam Pluralis. Islam Formalis terdiri atas parpol Islam yang berasas Islam (PPP, PKS, PBB, PMB, PBR, PKNU), dan Islam Pluralis yaitu partai yang berbasis massa Islam dengan Pancasila sebagai asas politiknya, yang masuk dalam kategori ini adalah PKB dan PAN.

Kehadiran partai Islam pada era reformasi ini tampaknya mengalami fluktuasi. Apabila pada Pemilu 1999, jumlah partai (yang berasas) Islam yang ikut pemilu sebanyak 17 partai. Pada pemilu 2007 menciut hanya tujuh partai, terus pemilu 2009 tinggal delapan partai politik Islam. Salah satu penyebabnya terus berkurannya partai Islam menjadi peserta pemilu karena ada adanya regulasi UU Pemilu yang menyulitkan partai tidak terkecuali partai Islam. Dalam UU No 10 Tabun 2008 tentang Pemilu ada aturan tentang parliamentary threshold (PT) 2,5 persen, aturan Daerah Pemilihan (Dapil) 310 kursi dalam setiap dapil, dan penggabungan sisa suara. Regulasi seperti itu menjadi berat bagi parpol-parpol Islam (dan juga parpol lainya) untuk dapat meraihnya.

Sama seperti pemilu-pemilu sebelumnya peta politik hasil Pemilu 2009 juga mengalami perubahan atau pergeseran. Apabila pada Pemilu 2004 yang keluar sebagai pemenang adalah Golkar kini Pemilu 2009 yang keluar sebagai pemenang adalah Partai Demokrat (PD) dengan mendulang suara sebanyak 20,85\%. Pada Pemilu 2009 ini Golkar tidak mampu mempertahankan posisinya, ia berada di posisi kedua dengan meraih suara sebanyak 14,45\%. Posisi ketiga ditempati oleh PDIP dengan mendapat suara $14,03 \%$. Urutan selanjutnya ditempati oleh PKS dengan suara 7,88\%, PAN 6,44\%, PPP 5,32\%, PKB 4,94\%, Gerindra 4,46\%, dan Hanura $3,77 \%$. Lalu bagaimana dengan kekuatan partai Islam?

Mencermati hasil perolehan suara dan kursi secara nasional pada Pemilu 2004 ini, nampak pergeseran peta kekuatan politik juga terjadi pada partai-partai Islam dan berbasis massa Islam. Partai-partai Islam kecuali PKS mengalami penuruan suara. Begitu juga dengan partai berbasis massa Islam. Keinginan partai Islam menjadi pemenang pemilu belum juga terlaksana. Alih-alih mencapainya, partai Islam dan berbasis massa Islam cenderung mejadi partai "papan tengah". 
Dengan kondisi tersebut sulit rasanya partai Islam dan berbasis massa Islam untuk berperan signifikan dalam proses dinamika politik di parlemen.

Hasil pemilu 2009 menetapkan hanya sembilan partai politik lolos dari Parliamentary Threshold (PT) atau ambang batas perolehan suara sebanyak 2,5 persen dari jumlah suara sah secara nasional pada Pemilu 2009 yang berjumlah sebanyak 104.099.785 suara. suara sah secara nasional dapat diikutkan dalam penentuan perolehan kursi Sesuai dengan Pasal 202 UU 10 Tahun 2008 tentang Pemilu Legislatif, parpol peserta pemilu yang memenuhi ambang batas perolehan sekurang-kurangnya 2,5 persen dari jumlah. Berdasarkan aturan ini maka urutan kesepuluh PBB yang hanya mendapatkan suara 1.864 .752 sekitar 1,79\% dinyatakan tidak lolos dari Parliamentary Threshold (PT). Lebih jelasnya berikut tabel hasil perolehan suara pemilu 2009.

Tabel X

Hasil Perolehan Suara dan Kursi Pemilu III Pasca Reformasi 2009

Peserta : 44 Partai Politik

\begin{tabular}{|c|l|r|r|c|}
\hline NO & NAMA PARTAI & \multicolumn{1}{c|}{ SUARA } & \multicolumn{1}{c|}{ \% } & \multicolumn{1}{c|}{ KURSI } \\
\hline 1 & Partai Demokrat & 21.703 .137 & 20,85 & 148 \\
\hline 2 & Golkar & 15.037 .757 & 14,45 & 108 \\
\hline 3 & PDIP & 14.000 .091 & 14,03 & 93 \\
\hline 4 & PKS & 8.206 .955 & 7,88 & 59 \\
\hline 5 & PAN & 6.254 .580 & 6,01 & 42 \\
\hline 6 & PPP & 5.533 .214 & 5,32 & 39 \\
\hline 7 & Partai Gerindra & 5.146 .122 & 4,94 & 30 \\
\hline 8 & PKB & 4.646 .406 & 4,46 & 26 \\
\hline 9 & Partai Hanura & 3.922 .870 & 3,77 & 15 \\
\hline
\end{tabular}

Sumber : www.partai.info/pemilu2009

\section{d. Pemilu IV Pasca Reformasi 2014}

Pemilu 2014 diikuti 12 partai politik. Sembilan dari partai politik itu merupakan pemilik kursi di DPR RI dan hanya ada satu partai politik baru yang lolos seleksi, yakni Partai Nasional Demokrat (Nasdem). Dengan demikian, enam dari 12 partai politik peserta pemilu beraliran nasional, yakni Nasdem, PDIP, Demokrat, Gerindra, Golkar, Hanura, dan Partai Keadilan dan Persatuan Indonesia. Sedangkan partai-partai berbasis Islam adalah PAN, PKS, PKB, PPP dan PBB.

Dari lima partai politik berbasis massa Islam yang menjadi peserta Pemilu 2014, hanya Partai Bulan Bintang (PBB) yang terbukti terpuruk perolehan suaranya berdasarkan perhitungan sementara hasil pemilu legislatif. Selebihnya? Melejit di atas kisaran 6 persen, termasuk partai-partai yang dihajar pemberitaan negatif seperti

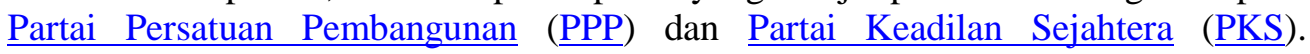
Lima partai berbasis massa Islam yang menjadi peserta Pemilu 2014 adalah Partai Kebangkitan Bangsa/PKB (nomor urut 2), PKS (3), Partai Amanat Nasional/PAN (8), PPP (9), dan PBB (14). Sementara PBB tidak lolos ke DPR karena perolehan suara kurang dari 3,50 persen. Lebih jelasnya berikut tabel hasil prolehan suara dan kursi pada pemilu tahun 2014. 


\section{Tabel XI}

\section{Hasil Perolehan Suara dan Kursi Pemilu IV Pasca Reformasi 2014} Peserta : 12 Partai Politik

\begin{tabular}{|c|l|r|r|c|}
\hline NO & NAMA PARTAI & \multicolumn{1}{|c|}{ SUARA } & \% & KURSI \\
\hline 1 & PDIP & 23.681 .471 & 18,95 & 109 \\
\hline 2 & Golkar & 18.432 .312 & 14,75 & 91 \\
\hline 3 & Gerindra & 14.760 .371 & 11,81 & 73 \\
\hline 4 & Demokrat & 12.728 .913 & 10,19 & 61 \\
\hline 5 & PKB & 11.298 .957 & 9,04 & 47 \\
\hline 6 & PAN & 9.481 .621 & 6,53 & 49 \\
\hline 7 & PKS & 8.480 .204 & 6,79 & 40 \\
\hline 8 & PPP & 8.157 .488 & 6,53 & 39 \\
\hline 9 & Nasdem & 8.402 .812 & 6,72 & 35 \\
\hline 10 & Hanura & 6.579 .498 & 5,26 & 16 \\
\hline 11 & PBB & 1.825 .750 & 1,56 & 0 \\
\hline 12 & PKPI & 1.143 .094 & 00,91 & 0 \\
\hline
\end{tabular}

Sumber : www.partai.info/pemilu2014

Jika mencermati tabel hasil perolehan suara dan kursi pada pemilu 2014 di atas, nampak bahwa kekuatan partai Islam belum bisa mengalahkan empat partai nasional yang menduduki urutan pertama sampai keempat. Lagi-lagi partai Islam pada pemilu 2014 hanya mampu mengulangi pemilu 2009 menjadi partai "papan tengah". Kondisi ini menjadi pekerjaan rumah bagi parai-partai Islam, kenapa belum mampu menjadi pemenang dalam pemilu sementara mayoritas pemilih Indonesia adalah beragama islam.

\section{E. Simpulan}

Partai politik berbasis Islam tidak bisa dipisahkan dari tiga dimensi waktu bangsa Indonesia, masa lalu, sekarang dan yang akan datang. Sejak pemilu pertama tahun 1955 sampai pemilu 2014 selalu menjadi bagian penting dari proses politik Indonesia, walaupun belum pernah menjadi pemenang pemilu. Jadi selama ada organisasi kemasyarakatan yang berbasis Islam, selama itu partai Islam akan selalu eksis dan berkibar dalam perpolitikan Indonesia.

Pada era sistem Parlementar saat pemilu pertama 1955 dilaksanakan, partai politik berbasis Islam banyak mendominasi. Bahkan Masyumi sama jumlah perolehan kursinya dengan PNI sebagai pemenang suara terbanyak yaitu 57 kursi. Disusul NU (Nahdlatul Ulama) yang menempati urutan ketiga dengan 45 kursi, kemudian PKI di rutan keempat dengan 39 kursi. Kemudian memasuki era Demorasi Terpimpin, terjadi krisis politik berkepanjangan sampai Presiden Soekarno diberhentikan oleh MPRS melalui Sidang Istimewa bulan Maret 1967 (Ketetapan XXXIV/MPRS/ 1967) setelah meluasnya krisis politik, ekonomi dan sosial pasca kudeta G 30 S/PKI yang gagal semakin luas, rezim yang kemudian dikenal dengan sebutan Demokrasi Terpimpin itu tidak pernah sekalipun 
menyelenggarakan pemilu. Namun di era ini partai politik berbasis Islam mengalami distrosi yang luar biasa.

Sepertinya ada gerakan pembusukan yang menyerang partai politik berbasis Islam. Terlebih pada pemilu pertama 1955 partai politik berbasis Islam memperlihatkan dominasinya dari segi perolehan suara dan kursi. Bisa jadi hasil pemilu 1955 ini menjadi warning kelompok lain yang sangat frustasi melihat fenomena Masyumi dan NU menempati urutan kedua dan ketiga perolehan kursi, sehingga harus didesain untuk menyingkirkan Masjumi dari arena politik Indonesia. Hasilnya luar biasa, ketika terjadi gejolak di beberapa daerah, Masyumi diidentifikasikan dengan pemberontakan tersebut sehingga pada tahun 1960 dua partai politik berbasis Islam yaitu Masyumi dibubarkan. Menyusul kemudian PSI.

Kemudian memasuki era Orde Baru, sistim kepartaian terus mengalami penyederhanaan. Lagi-lagi era ini partai politik bebarbasis islam mengalami musim paceklik keran sistem kepartaian dan pemilu sengaja didesain untuk mengkerdilkan partai-partai yang tidak beraafiliasi kepada pemerintah. Pada pemilu pertama tahun 1971 di era Orde Baru ini ada sembilan partai dan satu golongan berkarya (Golkar) peserta pemilu. Walaupun Golkar yang mendapat dukungan penuh dari kekuasaan tetap menjadi pemenang pertama pada pemilu 1971, namun urutan kedua sampai kelima didominasi oleh partai politk berbasis Islam. Berturut-turut pemilu berikutnya di era ini hanya dikuti oleh tiga peserta, yaitu Golkar yang selalu menjadi pemenang, diikuti PPP dirutan kedua dan PDI urutan ketiga.

Memasuki era Reformasi, Indonesia dilanda redemokratisasi. Suatu perubahan sistem politik dari sistem otoritarianisme menuju sistem demokrasi yang terbuka dan memberikan kebebasan kepada warga negara. Susana pada pemilu pertama tahun 1955 kembali terulang dengan bermumculannya beberapa partai politik baru termasuk partai berbasis Islam. Pada era Reformasi ini keinginan partai Islam menjadi pemenang pemilu belum juga terlaksana. Alih-alih mencapainya, partai Islam dan berbasis massa Islam cenderung mejadi partai "papan tengah". Dengan kondisi tersebut sulit rasanya partai Islam dan berbasis massa Islam untuk berperan signifikan dalam proses dinamika politik di parlemen. 


\section{Daftar Pustaka}

Azyumardi Azra, "Islam Politik pada Masa Pasca Soeharto". Kata Pengantar untuk A.M. Fatwa, Satu Islam Multi Partai (Bandung: Mizan, 2000).

Daniel S Lev, Pertai-Partai Poliitik di Indonesia Pada Masa Demeokrasi Parlementer dan demokrrasi Terpimpin, Dalam Ichlasul Amal, 1988, TeoriTeori Mutakhir Partai Politik, yogyakarta : PT Tiara Wacana.

Haryanto, 1982, Sistem Politik - Suatu Pengantar, Liberty, Yogyakarta

Miriam Budirdjo, 1994, Demokrasi di Indonenesia (Demokrasi Parlementer dan Demokrasi Pancasila), Jakarta : PT Gramedia Pustaka Utama

Miriam Budiardjo, 1991 Dasar-Dasar Ilmu Politik, Gramedia, Jakarta

Marzuki Wahid dan Rumaidi, Fiqh Mazhab Negara, Kritik atas Politik Hukum di Indonesia (Yogyakarta: LKiS, 2001), hlm. 26-28. Lihat juga Munawir Sjazali, Islam dan Tata negara, Sejarah, Ajaran, dan Pemikiran (Jakarta: UIPress, 1993)

Ramlan A. Surbakti, Memahami Ilmu Politik (Jakarta: Gramedia Widiasarana Indonesia, 1992).

\section{Jurnal :}

Ejournal.lipi.go.id 
